Relations industrielles

Industrial Relations

\title{
The Bargaining Process and Mediation, Toronto, Education Relations Commission, 1983.
}

\section{E. G. Fisher}

Volume 38, numéro 4, 1983

URI : https://id.erudit.org/iderudit/029416ar

DOI : https://doi.org/10.7202/029416ar

Aller au sommaire du numéro

Éditeur(s)

Département des relations industrielles de l'Université Laval

ISSN

0034-379X (imprimé)

1703-8138 (numérique)

Découvrir la revue

Citer ce compte rendu

Fisher, E. G. (1983). Compte rendu de [The Bargaining Process and Mediation, Toronto, Education Relations Commission, 1983.] Relations industrielles /

Industrial Relations, 38(4), 915-916. https://doi.org/10.7202/029416ar

Tous droits réservés @ C Département des relations industrielles de l'Universite Laval, 1983
Ce document est protégé par la loi sur le droit d'auteur. L’utilisation des services d'Érudit (y compris la reproduction) est assujettie à sa politique d'utilisation que vous pouvez consulter en ligne.

https://apropos.erudit.org/fr/usagers/politique-dutilisation/ 
Cet ouvrage sera d'un grand intérêt tant pour les étudiants que pour les praticiens de la gestion de la rémunération ou les gestionnaires en général. Il s'agit d'un travail important, remarquable et soigné. Il est très bien écrit. Tout y est exprimé avec clarté, précision et logique. Enfin, ce livre fait oeuvre de pionnier dans ce domaine pour les francophones d'Amérique.

\section{Jacques CHOUINARD}

Université Laval

The Bargaining Process and Mediation, Toronto, Education Relations Commission, 1983.

The Bargaining Process and Mediation, written by the (Ontario) Education Relations Commission, is a monograph devoted to analysing primarily the mediation process and necessarily the collective bargaining process, of which the former clearly is an adjunct. Understandably, the preface indicates that the "comments and opinions expressed in this document ... are not meant to be taken as a reflection of the official policy or views of the Education Relations Commission.» The monograph apparently is an outgrowth of the Commission's program for training the many part-time mediators it engages to meet the highly cyclical bargaining calendar confronting teacher unions and school boards in Ontario.

On the whole, this document is both well-organized and well-written. In the place of formal chapters are the following major headings: Introduction, The Stages of Bargaining, The Process of Bargaining, The Stages of Labour Mediation, Strategies and Tactics of Mediation, and Conclusion. The stages of bargaining identified are the standard ones: stage I - establishing the negotiating range, stage II - narrowing the range, stage III - the "crisis» preceding the decision to settle or invoke sanctions. The monograph correctly points out that these phases are «an abstraction». It adopts the four processes of bargaining identified and analyzed by Walton and McKersie in their classic text, A Behavioral Theory of Labor Negotiations: distributive bargaining, intraorganizational bargaining, attitudinal structuring (or maintaining and promoting harmonious relations), and problem-solving or integrative bargaining.

Several positive features of the Commission's work derive from and synthesize Walton and McKersie's orientation and analysis. For one, the monograph links together and emphasizes the possible impacts of the current round of negotiations on the types of future bargaining relationships (i.e., conflict, containment-aggression, accommodation, cooperation or collusion). For another, it stresses joint problem-solving, building trust and implicitly «relationships by objectives». In fact, considerable space is devoted to problem-solving, including singleteam bargaining. Despite the Commission's denial, this orientation (understandably) seems to reflect its views. Also implicit in the monograph are (somewhat ill-defined) notions about what constitute "mature» negotiations and «professional» negotiators. But, taken as a whole, the text contains a very balanced assessment of distributive bargaining, in particular.

The discussion of the bargaining process generally is quite successful in introducing the neophyte to the rituals and phasing of negotiations. However, it occasionally assumes a familiarity with negotiations or fails to introduce ken concepts during initial discussions. Presumably, it should spell out from the outset that each party tries to do the best it can for itself, yet often seeks a settlement that both parties can live with. The notion of «lateral thinking», which is so important for negotiators, is not mentioned until the section on mediation, possibly creating the false impression that only mediators are capable of mental gymnastics. The distinction between union issues and bargaining unit issues is not highlighted in the discussion of issues. Little attention is given to the principle that, ideally, negotiators should strive to 
budget negotiating time according to the importance of issues. Although the acronym PTR is used prior to page 32, PTR first is linked with the "pupil to teacher ratio» on that page.

The greatest amount of treatment is devoted, of course, to mediation. The (admittedly abstract) stages of mediation identified in the text are the traditional ones: stage I developing acceptability and diagnosing the situation, stage II - facilitating the bargaining process and stage III - creating pressures for settlement. The monograph envisages the mediator in a proactive role: well-prepared, clearly establishing the (recommended) ground rules and controlling the exchange of information, yet simultaneously emphasizing to the parties that the ultimate responsibility for settling rests on their shoulders.

Many useful insights for would-be or seasoned mediators are provided. Included are tips such as how to structure the agenda and control the mediation process in order to promote a greater amount of problemsolving, how to deal with recalcitrant committee members, how to "seed» on plant ideas with bargaining committees, and how to attempt to steer around or remove «boulders in the road» to settlement. Significantly, the sample memoranda of agreement provided are structured to obtain each team's ratification recommendation. Useful guidelines are presented for calling caucuses and joint sessions and for using «pressure points» effectively. The information about mediation, drawn from classic sources on mediation, represents a very useful compendium of "state of the art» mediation techniques. In addition, a wellchosen variety of problem exercises provided at the end of the text can assist the reader in thinking through or honing his/her mediation skills. Presumably, these exercises are used in the Commission's training sessions. The sections on mediation also can enhance the negotiator's understanding of the mediation process.
There is, however, a major flaw to the treatment of mediation. The text could be interpreted incorrectly as supporting the position that mediators seek «settlements at any costs». In other words, the ethical considerations of mediation are not fully explored. At a minimum, the monograph should contain a code of ethics to guide the Commission's mediators, as does Simkin's classic on mediation.

On the whole, I highly recommend the Commission's monograph to students and practitioners of collective bargaining and mediation, for it represents a very positive synthesis and contribution to the Canadian literature in these areas.

\section{E.G. FISHER}

The University of Alberta

Pluralità: Italia ed Europa nei conflitti industriali, par Umberto Romagnoli, Dimitri Weiss et al., Roma, ASAP, 1983, $288 \mathrm{pp}$.

Ce volume contient les Actes du colloque international du même titre qui a été organisé à Bologne les 27,28 et 29 mai 1982, conjointement par l'ASAP (Associazione sindacale aziende petrolchimiche e collegate a partecipazione statale) - autrement dit le groupement patronal du trust pétrochimique public ENI - et l'École de Perfectionnement en relations industrielles et du travail de l'Université de Bologne, avec la collaboration de l'AISRI - association italienne d'étude des relations industrielles.

Volume important, et pas seulement par son grand format. Et original, car l'ASAP, qui a revêtu également l'habit d'éditeur, a décidé d'y reproduire non pas les textes préparés à l'avance par les principaux intervenants, mais le dit, l'enregistrement de leurs contributions orales. 